\title{
Cultural Maintenance among the Circassian American Community of New Jersey
}

\author{
Prof. Bader S. Dweik (Corresponding author) \\ Dept. of English, Middle East University \\ Airport Road, P.O. Box: 383 Amman, 11831, Jordan \\ E-mail:drdweik@yahoo.com \\ Rana M Omar \\ Dept. of English, Middle East University \\ Jordan \\ E-mail: ranapshippi83@outlook.com
}

Received: January 26, 2016 Accepted: April 21, 2016 Published: June 24, 2016

doi:10.5296/ijch.v3i1.8942 URL: http://dx.doi.org/10.5296/ijch.v3i1.8942

\begin{abstract}
This study aimed to investigate the cultural elements that the Circassians of New Jersey have preserved after being in the State of New Jersey for more than 80 years. It also sought to reveal the factors that assisted them in preserving some of Circassian cultural aspects. The researchers used a mixed approach of qualitative and quantitative research methods to collect and analyze the data. A sample of 40 participants was chosen conveniently on the basis of availability to respond to sociolinguistic questionnaire in addition to holding open-ended interviews with another 10 participants. Results showed awareness to the Circassian culture and its bountiful facets along with high appreciation to the American culture. The cultural elements that are mainly preserved were food, folklore, music and Circassian celebrations. On the other hand, they preserved "Adiga Xabza" which is a group of social refined manners that are based on respect, honor, hospitality, responsibility, self-control, discipline, and good character which is passed naturally to generations. Historical awareness was only concerned with major historical events that mainly reflected the suffering of their ancestors. The role of the Circassian associations was essential. Home and family were the major factors that helped in maintaining some of the cultural elements.
\end{abstract}


Keywords: Culture, Maintenance, Circassian, American, Community

\section{Introduction}

Language is a system of words and signs that humans can communicate through. It is the major tool to share ideas and express feelings. Every nation is marked by its language which plays a significant role in its recognition in the whole world. Societies are monolingual, bilingual, or multilingual. There are several factors that make a society use two languages or more such as migration whether involuntary or voluntary, colonial policies as well as federations. (Spolsky, 1998) A number of Circassians settled in the United States of America, specifically the State of New Jersey due to its location on the eastern coastline and it is where the first settlers settled. They have established their community for the past 80 years. They are an ethnic group that shares many aspects by nature such as; language, traditions, customs and rituals. Language and culture play a significant role in the lives of ethnic groups. The change with the ebb and flow of cultural aspects and languages use among small ethnic groups in the United States of America is due to languages and cultural contact. However, language and culture maintenance boost ethnic groups to appreciate their existence in the American melting pot. On the other hand, the loss of language and culture means the loss of the beauty of individuality and ethnicity.

The Circassians of New Jersey are an ethnic group with their own cultural stance and their own language. As the result of three languages in contact, the usage of one of them will prevail and the others will be replaced. While some ethnic groups maintain their linguistic and cultural identities, others drop them and assimilate themselves in the new societies.

This study aims to explore the status of the language and culture among the Circassians of New Jersey/ U.S. It also attempts to investigate the cultural elements that are preserved in their community, and to determine the factors that have aided them to preserve their ethnic culture. The study is guided by the following questions:

1. What are the cultural elements (categories) that the Circassians of New Jersey have preserved?

2. What factors have helped them to preserve their culture?

Although many studies were conducted on ethnic groups in the United States of America, very few if any were conducted on the Circassians of New Jersey. Hence, this study is an attempt to fill this gap. While many linguistic investigations have explored large communities; this study examined a small ethnic group in the United States of America, which may benefit other researchers who are interested in small ethnic communities.

\section{Review of Literature}

\subsection{Theoretical Literature}

Culture plays an important role in the lives of individuals and communities. Cultural maintenance refers to two factors 1 . The efforts that are taken to maintain one's ethnic culture, (2) the efforts that are taken to defy assimilation. Maintenance should be fulfilled on both 
levels, individuals and groups. In Diaspora communities in the United States, ethnic groups established institutions that would allow them to preserve their culture at a group level. It has been reported that heritage language schools, mosques, churches, and other ethnic organizations, to a great extent, have contributed to ethnic cultural maintenance among ethnic groups (Ward 1976).

Nahirny et al (1966) discussed the importance of culture as the major element of identification:

Culture is very important for individuals and communities. It is considered the major element of self-identification within the society. Nations take pride in their cultures and they try their best to hold onto their ethnic heritage. Both ethnic communal life and ethnic heritage came largely to depend upon and be sustained by such purposively devised organizational bonds. Only through participation in ethnic organizational life could the immigrants, and even more so their native-born children, reassert their ethnic solidarity as well as express their attachment to ethnic values and traditions ( p . 352)

Similarly, Newmark (1988) stated that "culture is the way of life and its manifestations that are peculiar to a community that uses a particular language as its means of expression. More specifically, he distinguishes 'cultural from 'universal and personal language." (p. 94). He also discusses cultural elements such as; (1) ecological: flora, fauna, winds, plains and hills, (2) material culture (artifacts): (a) food (b) clothes (c) houses and towns (d) transport, (3) social culture, work and leisure, social events, folklore, (4) organizations, customs, activities, procedures, concepts, (a) political and administrative: (b) religion (c) artistic and (5) gestures and habits, greetings.

Kipp \& Clyne (1997) discussed the factors that enhance cultural preservation. It includes size and distribution of an ethnic group, the status of the language within the cultural value system of the group, marriage patterns, reasons of immigration, age, gender, education, the policy of the host country towards ethnic minority languages, prior knowledge of the majority language, and language variety.

Myers-Scotton (2006) recognized the following societal, in-group and individual factors that are central to language and culture maintenance: 1. demographic factors - large numbers of speakers of the same ethnic language living together; 2. occupational factors - working with fellow speakers of the ethnic language, with restrictive socio-economic mobility; 3 . educational factors - e.g. official provision of the ethnic language as a medium of instruction; 4. social networks and group attitudes about the ethnic language as an ethnic symbol; 5 . psychological attachment to the ethnic language for self-identity. (p.90)

\subsection{Empirical Studies}

Dweik (1999) investigated the language situation among the Circassians of Jordan. The researcher used interviews and a questionnaire based on Fishman (1966). The questionnaire consisted of five parts: 1) language background, 2) language proficiency, 3) domains of language use, 4) attitudes towards language, and 5) demographic and social background of 
the informants. He concluded that the Circassians of Jordan maintained their language and culture after spending over a hundred years in Jordan.

Similarly, Dweik (2000) conducted a study that illustrated the ways in which the Chechen language and culture were preserved. Although the Chechens have settled in Jordan for more than 100 years, they maintained their language and culture. Data were collected by means of a questionnaire that consisted of language proficiency, language use, and language attitudes. The researcher also used interviews with the help of some assistants. The findings of the study were that the Chechens of Jordan preserved their language and culture, and developed a societal bilingualism

Al-Khatib and Al-Ali (2005) investigated language and cultural maintenance among the Gypsies of Jordan and their use of both Arabic and Gypsy. Data were collected by means of a questionnaire and interviews. The sample consisted of 100 participants. Results presented that Arabic is used in multiple areas and Gypsy is used in certain social domains such as home, neighborhood, religious and social gatherings. Language maintenance is associated with the fact that the Gypsies cannot access the majority of the Jordanian society with easy manner. Gypsies' social isolation from Jordanian society was the major reason why cultural and language maintenance occurred.

Alzoubi (2007) examined the language and cultural maintenance among the Druze of Jordan. The study aimed to investigate the factors that contributed to language and culture preservation. Data were collected by personal observation, personal interviews and a questionnaire that covered domains of language use, language proficiency, and attitudes towards mother tongue and the Bedouin dialect. In conclusion, the Druze of Jordan maintained their dialect within the Druze social encounters. Beside they were proficient in the Bedouin dialect with different usage among females. Regarding cultural preservation, it was noted that religious and social isolation, internal marriages played a major role in cultural preservation.

MlntStud (2008) investigated the cultural values and ethnicity among the Druze of Southern Australia. The framework of the study was based on the Humanistic Sociology, which means that social and cultural experiences can be only understood and studied from the point of view of the respondents. Data were collected by intensive interviews with a small group of Druze living in South Australia. The outcomes of the study were that Druze community in South Australia maintained their cultural values and identities with some changes due to the modernization on some traditional values and social protocols, such as marriage and family values.

Otcu (2010) examined the role of the Turkish Saturday School which is part of Turkish Consulate in Manhattan. The goal of the school was to help the Turkish students living in New York to preserve their language and cultural heritage. The sample of the study consisted of 23 respondents including students in Pre-K till Fifth grade, teachers, parents, and administration. Data were collected by observation through audio or video-recording, semi-structured interviews. Observations produced 49 sets of field notes, about 22 hours of audio-recordings, and 8 hours of video-recordings. The findings of the study were that the 
first generation which is presented by the parents holding to the Turkish language, values and traditions. Moreover, the children have hybrid identities. They reject the idea of their parents speaking English to their rivals at the school.

Glasgow (2012) explored the Croatian language and cultural maintenance in Kansas. The sample of the study consisted of 20 participants. Data were collected by structured interviews using Expanded Graded Intergenerational Disruption Scale (EGIDS, Lewis and Simons (2010). Results of the study were the first wave of immigrants has no proficiency in Croatian language. On the other hand, the second wave shows high levels of bilingualism. On A cultural level, they maintained some aspects from the Croatian culture such as food, greetings, and music.

\section{Methodology}

The researchers used a mixed approach of qualitative and quantitative research methods to collect and analyze the data. The population of the study included first, second and third generations of the Circassians who reside in the state of New Jersey. A sample of 40 participants were chosen conveniently on the basis of availability to respond to the questions of the study .The sample consisted of first, second and third generations, whose ages range between 10-50. The sample included a wide scope of diverse demographic information i.e. gender, age, place of birth, marital status, occupation and have a diverse range of educational levels while a number of the participants holding MA degrees, BA degrees, while others hold college degrees, and high school diplomas. The researchers used the 'social network' proposed by Milroy and Milroy (1978) to communicate and correspond with the participants through a third party. They were helped by two assistants who belong to the Circassian community. The researchers used two types of instruments related to cultural preservation, and the factors that stood behind the Circassian cultural preservation. The first instrument was open-ended interviews that put forth questions which offered a great deal of insight about cultural elements. Interview questions were adapted from Wither (2003) in her study of the Hmong Language and Cultural Maintenance in Merced City, California. Some of the interviews were held via Skype, phone calls, Viber, emails, while personal interviews were conducted with some of the Circassians of New Jersey who visited Jordan during July, August and September 2014.The second instrument which was employed in this research was a sociolinguistic questionnaire that was based on similar questionnaires which were used by previous studies that dealt with ethnic groups locally and internationally such as Dweik (2000) and Wither (2003). The questionnaire consisted of two sections that aimed to answer the questions of the study. The first section, dealt with the demographic data of the participants such as age, gender, place of birth, marital status and occupation. The second section of the questionnaire, dealt with the factors that help in preserving the culture. This part consisted of 12 statements that reflected the respondents' attitudes towards the factors that helped in cultural preservation among the Circassian community. The choices were based on a five-item Likert scale that showed the degree of the respondents' agreement or disagreement. 


\section{Results}

\subsection{Results of Question One}

What are the cultural elements (categories) that the Circassians of New Jersey have preserved?

To be able to answer this question, the researchers used open-ended questions in the interviews. The interviews were conducted with ten individuals who represent three different generations. The first generation was represented by the immigrants who migrated to New Jersey 30-50 years ago. The second generation was displayed by those who were born in New Jersey to Circassian immigrant parents. Finally, the third generation was portrayed through being born to Circassian parents who belong to the second generation.

Results of the interviews showed that Circassian and American cultures coexist side by side in the lives of the Circassians of New Jersey. All the interviewees indicated a good amount of awareness to their Circassian culture and its bountiful facets alongside with high appreciation to the American culture. Results of the interviews were categorized based on the following cultural aspects that were preserved among them:

Adiga Xabza

All the interviewees made it clear-cut that the Adiga Xabza is the most important principle that guided their lives. Adiga Xabza is a group of social refined manners that are based on respect, honor, hospitality, responsibility, self-control, discipline, and good character which is passed naturally to generations. Home is the first place where children learn and apply these social standards.

Osama Kataw (66 year old man) stated that "I was born in Jordan to two Circassian parents and they made sure that Adiga Xabza was followed inside and outside our home. I have two boys that were born in New Jersey. I tried to raise them according to Adiga Xabza but it was not an easy task because the American culture is totally different from the Circassian one. It is a must for us to interact with Americans and other groups due to many reasons such as schools, colleges, and work"

Jonty Ymaisha (37 year old man) stated that "I was born and raised by two Circassian parents in NJ, and I lived my life under the rules of conduct (Xabza) that my ancestors observed. I have updated my practice for the modern age, but I continued to display the warmth, respect, honor and hospitality... first among my own family, then to the greater Circassian community and finally to all people." He told the researchers a story to confirm the respect and hospitality which the Circassians still hold on to this day "To me, being Circassian is about honor, respect and hospitality. There is an old Circassian story about a mother of a local prince who led his village into battle against the Russians. Her son was killed in battle, as was the local Russian general who led the Russians. Afterwards, the dead were brought back to the prince's house to be identified and buried. His mother lived with him. When they told her that the Russian general was among those who were killed and was in the house next to her son, she demanded that the general be given the most highly respected place in the house and 
that her son be moved to the back. Why? "We have a guest among us." This story may sound strange to non-Circassians. It may sound strange to Diaspora Circassians, but it demonstrates the extent to which Circassians value respect, honor and hospitality."

Abraham Tsy (36 years old man) said "Adiga Xabza was passed to me through my parents, they were strict when it came to the way I was expected to behave as a Circassian. Home is the basic domain where language and Adiga Xabza are taught and applied."

Shan Jatkr (16 year old young man) "I was raised by Circassian standards. I was expected to speak politely to elders and behave according to the Circassian manners. I don't know Adiga Xabza in details and why we act according to it, but I behave automatically the way I am expected to behave"

\section{Circassian History}

The majority of the interviewees showed a certain simplified awareness about the Circassian history and the suffering that their ancestors went through after the Russians occupied their country and removed them off from their homeland... All the interviewees acknowledged the date of the Genocide May 21st as Circassian Memorial Day. The majority is keen about what the Circassian flag stands for, they knew that the 12 stars stand for the 12 Circassian tribes while the three arrows symbolize peace. Some of the interviewees had more knowledge about the Circassian history due to their own interests in reading about the Circassian history.

Zack Barsik (45 year old man) stated that "I read a lot about my homeland and the history of my ancestors. Our present means nothing if we don't know our history."

Dana Wojoukh (27 year old teacher at the Sunday school) said "I voluntarily teach Circassian language, history and traditions at the Sunday School located in the CBA (Circassian Benevolent Association), history is part of my curriculum and I teach it in a simple way to my students. I know that history is part of our culture and we should all know about it."

It seemed that most of the interviewees had good knowledge of some of the major cities in their mother land such as Maykoop, Nalchik, Sochi, Nartqala, and Charkess.

\section{Circassian Food}

Circassian food is one of the cultural elements that all the respondents praised and enjoyed on occasions and on regular basis. "Ships Pasta" is the Circassian traditional meal that is mostly eaten among the three generations. Haliva, Adiga Qwaya (Circassian cheese) and Laqum were also highly enjoyed. Starting with Ships Pasta, the components of Ships are baked flour and walnut boiled with chicken stock put on Pasta which is made of rice and groats cooked together, then served with grilled chicken. Second, Haliva is made of stuffed dough with potato or cheese. Third, Adiga Qwaya is made of milk and sour rennet. Finally, Laqum is made by a sweet dough which is rolled to a thickness of no greater than $5 \mathrm{~mm}$, and then cut into pieces of any size. They are placed in a hot pan and fried. Women cook Circassian food at home to their families on regular basis and on social occasions. The way to cook Circassian meals was passed by older women in the families to younger ladies. In addition, Circassian food can be ordered from the CBA cafeteria. 
Linda Brouk (35 year old woman) said "My mother-in-law taught me how to cook Ship Pasta and make Adiga Qwaya, my whole family enjoys them." She added "cooking Ships Pasta needs patience, and it demands a good amount of time and effort to cook it"

Anya Wenuj (34 year old woman) said "I cook to my family and friends Ships Pasta and we all enjoy it."

\section{Circassian Folklore}

Circassian folklore became the major feature that distinguishes Circassians from other ethnic groups all over the world. All the interviewees knew the Circassian folklore dancing and how it was performed, even though some of them did not perform it. Most of them were able to name different kinds of performances such as Qafa, Chechen, Wij, Thaparepha, and Isalameh. On the other hand, a great realization to the Adiga Fasha (Circassian traditional costumes) was noticed through the interviews. Most of the interviewees were able to describe both female and male traditional outfits including Qalbaq, Harez, and Qama. The traditional costumes are worn mainly in performances and some ladies wore the Adiga Fasha as wedding gowns. Folklore dancing is performed during weddings, social events and on certain occasions held by the CBA. Nart Ensemble or other Circassian dancing groups coming from other countries perform in New Jersey and other states. Shan Jatkr (16 years old) stated "I am a part of the Narts Ensembl. We practice two times a week, and we did many performances in many occasions" On the other hand, Janet Kaghado (36 years old) said "The wedding's ceremonies always start with a Jug which is a circle that all people gather to start the Circassian dancing where everyone kicks heels. The ladies stand on the right, while the men stand on the left side, and the whole Jug is supervised by the Hatyakwa who is in charge of the turns of the dancers."

Anya Wenuj (34 year old woman) stated that "My daughters are part of the Narts Ensemble and I am proud that they can dance and socialize with their Circassian peers at the CBA."

\section{Circassian Music}

Based on the interviews, all the interviewees expressed a high appreciation to the Circassian melodies. As known to all Circassians, each Circassian routine has certain tunes that are played along with it. All of respondents knew that Circassian music varied according to the type of the dance. Additionally, all of them are familiar with Circassian instruments which are used to produce Circassian music such as Pshina, Baraban, Bkhashasha, and Checkpshina. The most famous song that was well known among the interviewees was Sinana Dakha which is a song that celebrates mothers.

\section{Circassian Celebrations}

According to the interviews, the Circassians of New Jersey usually celebrate Adiga Day on September $14^{\text {th }}$ where the majority of the Circassians of New Jersey gather at the CBA and spend the day together as a whole community. There are many activities for children and adults. The CBA holds many events such as Ladies Night, Pshinawa Night, and Game Day for the children. They also celebrate Eid Feter, Kurman Day which stands for Adha Eid. They 
also observe the Genocide Day on May 21st. As American citizens they celebrate Thanksgiving and 4th of July. On the other hand, they do not celebrate Christmas nor Easter.

Osama Kataw "We gather as a community in many accessions, like Adiga Day, Kurman Day, Eid Feter, weddings and other accessions. You will be surprised you can hear the three languages spoken in one place although English is spoken by the majority of the younger generation."

Zack Barsik (45 years old man) commented on the celebrations "celebrate as many celebrations as I can, if I remember them, or made aware of them....for example as a child I practiced the "Summer Solstice" and "Winter Solstice"...this coming week December 22 my family will sit and celebrate the "Winter Solstice" (Birth of the Sun...Digheghaze) My family tries as much as possible to hold Circassian traditions in any of our family weddings. Circassian New Year's Day on March $22^{\text {nd }} \ldots$ We commemorate on May $21^{\text {st }}$ as Circassian Genocide Day of Remembrance where all Circassians on earth share this historic tragedy. As children, my mother used to have my family and friends (kids all our age) have a procession for Hentsiygqasche, Goddess of Rain where we would walk on our property chanting for Rain...I have not done this with my kids. When my first son began to walk, my mother celebrated his first steps by making sweets and sharing with the family."

Allan Kadkoy (35 year old) emphasized "I only celebrated Adyga Shogha Maxwa (Circassian Memorial Day on May 21st) I'm planning to start celebrating Adyga ancient holidays such as Dighe Ghaze and Tehashxuagohaj starting this year"

\section{Circassian Cultural Organizations}

CBA is the major social place where the Circassians of New Jersey gather as a community. Some of the interviewees are active members at the CBA. They go and spend their free time with some friends. Mai Khamash (34 year old) stated "I usually go and spend some time at the CBA with my husband and friends. It's the place where we as Circassians socialize with other Circassian friends."

Eddie Kaghol (36 year old) "I am part of the CBA community, I hang out there with my friends." While others stated that they did not have the free time to go to every occasion that the CBA holds due to their busy schedules.

Janet Soubr (32 year old) commented that "Due to the expensive living circumstances in the United States, both me and husband work, so we have a busy schedule, but we try our best to attend social events. Unfortunately, we cannot attend all of them." Some of the interviewees were dissatisfied with the CBA's achievements, their point of view was that the CBA had failed to join all the members of the society together in one hand and did not address the linguistic, social, and cultural struggles that the community is facing especially the young generations on the other hand.

Zack Bersik was dissatisfied with the language and cultural situation among the Circassians of NJ. He commented that "the Circassian language is not used anymore among the youth and it is replaced with English." He stated that "the external marriages are increasing among 
the young people due to the openness to the American society." He made it clear that the "Circassian Culture became exclusively presented by dancing and music and that was part of the Russian agenda is to abolish the Circassian identity among Circassians all over the world not only in New Jersey." He elaborated that "the Circassian organizations role in culture maintenance should be more sufficient and it should be taken in a more serious manner."

\subsection{Results of Question Two}

What factors have helped them to preserve their culture?

This question aimed to explore why some of the Circassian cultural elements were preserved among the Circassians of New Jersey. Table (1) presents the degree of the respondents' agreement or disagreement with the factors that helped in preserving some cultural aspects of the Circassian culture. A quick glance at Table (1) shows that the statements from one till nine show high degree of agreement. While statements ten, eleven and twelve show medium degree of agreement.

The following equation was used to determine the level of agreement: Interval Width = (Maximum Point - Minimum Point) $\backslash$ Number of Levels Interval Width $=(5-1) \backslash 3=1.33$

- $\quad$ From 1 to 2.33 is considered low level of agreement

- From 2.34 to 3.67 is considered medium level of agreement

- From 3.68 to 5 is considered high level of agreement

Table 1. Factors that helped in preserving the Circassian culture

\begin{tabular}{|c|c|c|c|c|}
\hline \multicolumn{2}{|r|}{ Statement } & Mean & $\%$ & L. A.* \\
\hline 1 & Family has a significant role in cultural preservation. & 4.7 & 94 & High \\
\hline 2 & Home has a significant role in cultural preservation. & 4.6 & 92.5 & High \\
\hline 3 & $\begin{array}{l}\text { Motivating children by parents to learn the Circassian traditions } \\
\text { helps to preserve the culture. }\end{array}$ & 4.6 & 92 & High \\
\hline 4 & The pride in being a Circassian helps in preserving the culture. & 4.6 & 91.5 & High \\
\hline 5 & $\begin{array}{l}\text { The close relationships among the community members help to } \\
\text { preserve the culture. }\end{array}$ & 4.4 & 87.5 & High \\
\hline 6 & $\begin{array}{l}\text { Community associations play a positive role in preserving the } \\
\text { culture. }\end{array}$ & 4.2 & 83 & High \\
\hline 7 & $\begin{array}{l}\text { Learning the Circassian language is essential to maintain the } \\
\text { Circassian identity. }\end{array}$ & 4.1 & 81.5 & High \\
\hline 8 & $\begin{array}{l}\text { The elder members of the community play a positive role in } \\
\text { culture preservation in passing the traditions. }\end{array}$ & 4.0 & 79.5 & High \\
\hline 9 & $\begin{array}{l}\text { The democratic atmosphere in the USA gives the freedom to all } \\
\text { Circassians of New Jersey to practice their language and }\end{array}$ & 3.9 & 78.5 & High \\
\hline
\end{tabular}




\begin{tabular}{|l|l|c|c|c|}
\hline & traditions. & & & \\
\hline 10 & $\begin{array}{l}\text { The ongoing suffering from the Diaspora encourages members } \\
\text { of the Circassian community to preserve the culture. }\end{array}$ & 3.6 & 71.5 & Medium \\
\hline 11 & $\begin{array}{l}\text { The internal marriage among group members helps them } \\
\text { preserve their culture. }\end{array}$ & 3.2 & 63 & Medium \\
\hline 12 & $\begin{array}{l}\text { Living in isolated Circassian environment may help to preserve } \\
\text { both language and culture. }\end{array}$ & 3.1 & 62 & Medium \\
\hline
\end{tabular}

Key: L.A.: Level of Agreement

Data extracted from Table (1) show that the role of the family in preserving the culture scored $94 \%$ among the respondents which is the highest score among all the factors that assisted in maintaining the culture. It indicates that the majority of the respondents believe that the family has the most significant role in passing culture and traditions to younger generations with the purpose of preserving it. The answers also indicate that home has a great role in preserving the culture through observing the traditions and customs among family members, so children can get aquatinted with these traditions and practice them first at home, then in the community. This factor has scored the highest level of agreement by the respondents. Motivating children by parents in learning and applying cultural traditions scored $(92 \%)$ which is also an indicator that family and home are essential in preserving the culture.

Results also indicate that the majority of the respondents believe that taking pride in being a Circassisn plays a significant role in cultural preservation. Being proud as a Circassian scored $(91.1 \%)$ with a mean of (4.6). On the other hand, the role of having good relations in the community registered $87.5 \%$. Furthermore, the positive role of the Circassian associations helped to preserve their culture scored a high level of agreement (83\%) and a mean of (4.2).

Results of statements 10,11, 12 showed medium degree of agreement. Data of Table (1) revealed that living in an isolated environment got the least percentages among all $(62 \%)$ with a mean of (3.2). On the other side, the respondents' answers registered medium agreement about the internal marriage among group members which may help in preserving the culture. Finally the ongoing suffering from the Diaspora encouraged members of the Circassian community to preserve the culture scored $(71.5 \%)$.

\section{Discussion and Conclusions}

\subsection{Discussion}

The first question tackled the cultural elements that the Circassians of New Jersey have preserved. Interviews provided significant insight about the cultural elements that are preserved among the Circassian community of New Jersey. All the interviewees highly praised Adiga Xabaza as the refined approach of behaving and that it is passed naturally from grandparents to parents and then to children. Home is the only place where children are taught to behave according to the Adiga Xabza.

The interviews showed that all the interviewees expressed high appreciation of the Circassian 
food and that it was enjoyed by all respondents. Food is a major element that is preserved among the Circassians of New Jersey. Similarly, music and folklore are practiced and preserved by them. They showed high consciousness towards their Circassian folklore and music. However, Circassian history was recognized by the interviewees only through the major events that happened to their ancestors. The role of the Circassian associations was praised to some extinct, some of the interviewees were not satisfied with the accomplishments nor the activities that were held by the associations. As Muslims, they do not celebrate Charismas or Easter, but as Americans they celebrate the $4^{\text {th }}$ of July, Thanksgiving and other national holidays. The findings of question one agree with the results of MlntStud (2008) which investigated the cultural values maintenance of the Druze of South Australia who maintained some of their cultural values. In addition, the results went in line with Chiu (2003) who stated that the Indians of Hakkas maintained their ethnic identity through food. This is followed by Glasgow (2012) who declared that the Croatians of Kansas - U.S.A have maintained some of their cultural elements such as food, greeting, and music. The results of the study went side by side with the study conducted by Octu (2010) where the Turkish groups in New York have maintained their traditions and cultural values.

In addition, the results supported other local studies that were conducted in Jordan. Dweik (2000) conducted a study to investigate the language and cultural situation among the Chechens of Jordan. The study showed that the Chechens of Jordan preserved their language and culture. Furthermore, the results were similar to the findings of Alzoubi (2008) who stated that the Druze of Jordan maintained their language and culture. Al-Khatib \& Al-Ali (2005) found out that the Gypsies of Jordan preserved their culture and language. It is worth mentioning that ethnic groups living in tolerant societies preserve some parts of their cultural heritage.

Results also showed that the Circassians of New Jersey are aware of the role of some factors in preserving their culture. These factors include domestic factors such as the role of home and family, historical factors such as their awareness in the Circassian history and the pride in their ethnic origin. It also shows that other social factors such as the strong relationships among the members of the community accompanied by the internal marriage and the role of the Circassian associations played a role in preserving their culture. Similarly, the democratic atmosphere in the U.S.A provides the freedom to all Circassians of New Jersey to practice their cultural heritage. The major factor that really helped in culture preservation was family alongside with the impact of the home in passing on the traditions and practicing them. The majority showed positive agreement about motivating children to learn and practice the Circassian traditions along with learning the Circassian language.

\subsection{Conclusions}

An overall analysis of the questionnaire and interviews indicates that the Circassians of New Jersey were able to preserve a good amount of the cultural elements that still play an important role in their Circassian ethnic identity. The study also concluded that:

1. The cultural elements that are mainly preserved were Circassian food, folklore, music, history and manners. 
2. Historical awareness was only concerned with major historical events that mainly reflected the suffering of their ancestors.

3. The role of the Circassian associations in New Jersey was praised to some degree.

4. Home and family were the major factors that helped in maintaining some of the cultural elements, along with the feeling of pride with their ethnic identity.

\section{References}

Al-Khatib, M., \& Al-Ali, M. (2005). Language and cultural maintenance among the Gypsies of Jordan. Journal of Multilingual and Multicultural Development, 26(3), 187-215.

Alzoubi, A. (2007). Language and cultural maintenance among the Druze of Jordan. (Unpublished M.A thesis), Jordan University of Science and Technology. Irbid: Jordan.

Chiu, S. (2003). Ethnic identity formation: A case study of Caribbean and Indian Hakkas in Toronto. (Unpublished MA thesis), York University, Toronto, Ontario.

Dweik, B. (1999). The language situation among the Circassians of Jordan. Albasaer, 3(2), $10-28$.

Dweik, B. (2000). Linguistic and cultural maintenance among the Chechens of Jordan. Language, Culture and Curriculum, 13(2), 184-195.

Gans, H. (1979). Symbolic ethnicity: The future of ethnic groups and cultures in America. Ethnic and Racial Studies, 2(1), 1-20.

Glasgow, H. (2012). Croatian language andf culture maintenance in the Slavic American community of strawberry hill Kansas City - Kansas. (Unpublished M.A thesis), University of Kansas. Kansas: U.S.A.

Milroy, J., \& Milroy, L. (1978). Belfast: change and variation in an urban vernacular. In P. Trudgill (Ed.), Sociolinguistic patterns in British English (pp. 19-36). London: Arnold.

MIntStud, D. (2008). Cultural maintenance and identity among members of the Druze Community in South Australia. School of international studies. University of South Australia. Australia.

Myers-Scotton, C. (2006). Multiple voices: An introduction to bilingualism. Malden. USA: Blackwell Publishing.

Newmark, P. (1988). A textbook of translation. New Jersey: Prentice Hall.

Otcu, B. (2010). Heritage language maintenance and cultural identity formation: The case of a Turkish Saturday school in New York City. Heritage Language Journal, 7(2), 112-137.

Spolsky, B. (1998). Sociolinguistics. Oxford: Oxford University Press.

Ward, C. (1976). The Serbian and Croatian communities in Milwaukee. Theme issue, The Dilemma of the Melting Pot: The Case of the South Slavic Languages. General Linguistics, 16(2-3), 151-165. 


\section{Macrothink}

International Journal of Culture and History

ISSN 2332-5518

2016, Vol. 3, No. 1

Withers, A. (2003). Hmong language and cultural maintenance in Merced City, California. (Unpublished doctoral dissertation). Retrieved from Proquest Dissertations and Theses.

\section{Copyright Disclaimer}

Copyright for this article is retained by the author(s), with first publication rights granted to the journal.

This is an open-access article distributed under the terms and conditions of the Creative Commons Attribution license (http://creativecommons.org/licenses/by/3.0/). 